\title{
FULL SCALE TANK CAR COUPLER IMPACT TESTS
}

\author{
Matthew L. Lyons \\ William T. Riddell \\ Volpe National Transportations Center, DTS-76 \\ US Department of Transportation \\ Cambridge, MA 02142
}

\author{
Kevin D. Koch \\ Transportation Technology Center, Inc. \\ P.O. Box 11130 \\ Pueblo, CO 81001
}

\begin{abstract}
Full scale tests were performed to investigate various aspects of tank car behavior during coupler impacts. A tank car was equipped with 37 accelerometers and an instrumented coupler. Two series of full scale coupler impact tests, comprising 26 impacts, are discussed. In the first series, the tank car was empty. In the second series, the tank car was full. A range of impact speeds was investigated. Accelerometer response and coupler force were measured for each test.
\end{abstract}

Aspects of the tank car response to coupler impacts can be determined by studying the coupler force versus time relationship, Shock Response Spectrum (SRS), and Power Spectral Density (PSD) analyses of accelerations measured on the tank car body. The dominant draft gear load transfer mechanism can be determined from the coupler force vs. time relationship. Accelerations were measured at many locations on the tank car. However, based on preliminary analyses, a single location near the manway was chosen for detailed study. SRS results of accelerations at this location show good correlation with the peak coupler force, although different relationships were observed when the car was empty than when it was full. PSD analyses of empty tank cars have peaks at different frequencies than PSD analyses of full tank cars, so a PSD analysis could be used to determine whether a car is empty or full. Therefore, the combination of SRS and PSD results suggests the possibility of estimating peak coupler forces resulting from yard impacts based on SRS and PSD analyses of accelerations measured at a single location on a tank car.

\section{INTRODUCTION}

Load history is an important aspect of the design and longevity of tank cars. It is believed that many of the largest coupler-force events encountered by tank cars are induced by rail yard impacts. The Tank Car Operating Environment (TCOE) task force was formed by the Association of American Railroads, the Chemical Manufacturers Association (now the American Chemistry Council) and the Railway Progress Institute (now the Railway Supply Institute) liaison team to study rail yard coupler impacts. Representatives from industry and the U.S. and Canadian regulators participated in this task force and interacted with the Stub Sill Working Group, which is interested in developing load histories for use in damage tolerance analyses. These groups concluded that there were not sufficient data to assess the frequency or severity of largecoupler-force events. Therefore, a study of the technical requirements for a system to remotely monitor coupler forces on tank cars operating in revenue service was performed [1].

The largest coupler force events are thought to occur infrequently. Therefore, the operating environment must be sampled with some combination of large sample size and long sample time to properly characterize the largest coupler force events. Furthermore, the measurement system should not be readily visible so that the measurement cars do not receive special treatment in railyards. In light of these requirements, an accelerometer-based system was recommended as a means to monitor coupler forces resulting from yard impacts. The first step toward developing such a system was to perform a series of full-scale impact tests [2]. These tests involved rolling an empty tank car into a stationary consist. The results of these tests showed a poor correlation between peak accelerations and 
peak longitudinal coupler force. However, there was a good correlation between the shock response spectrum (SRS) [3] of measured accelerations and peak longitudinal coupler force. To develop a system that is applicable to in-service conditions, the effect of different impact configurations, tank car design, and lading in the tank car must be accounted for in the relationship between coupler force and dynamic response. However, this series of tests considered only an unloaded tank car in a single impact configuration. The next step toward developing a useful system to monitor coupler forces is to account for lading in the tank car. Therefore, a second series of tests was performed with the same configuration, but with the tank car full. The purpose of this paper is to discuss relationships between structural response, coupler force, draft gear behavior, impact speed, and tank car lading during coupler impacts during these two test series. In addition to the test variables (impact speed and whether the car is empty or full) the primary draft gear mechanism that results from the impact also affects the response of the tank car. A systematic study of these effects will help to identify and gain confidence in any empirical relationships that are developed as a result of these tests.

\section{EXPERIMENTAL PROCEDURE}

The impact configuration, equipment, instrumentation and the experimental measurements taken during the testing are discussed in this section.

\section{Test Configuration}

Two series of tests are discussed in this report. In each test discussed in this report, an instrumented tank car (the hammer car) was rolled into a stationary consist of three full hopper cars (the anvil cars), as shown in Figure 1. In the first series of tests, the tank car was empty. In the second series of tests, the tank car was full. The brakes of the last hopper car in the consist were applied for all impacts. Strains, accelerations and the longitudinal coupler force were recorded as a function of time for each impact.

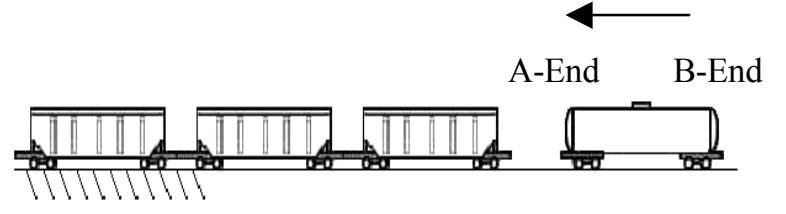

Figure 1. Configuration of impact tests.

The series of empty tank car impacts consisted of nominal impact velocities of $3,6,10$, and $13 \mathrm{~km} / \mathrm{h}(2,4,6$, and $8 \mathrm{mph})$. For each impact at $13 \mathrm{~km} / \mathrm{h}$, there was from 80 to $130 \mathrm{~mm} \mathrm{(3} \mathrm{to}$ 5 in) of movement in the anvil string. During the other impacts in this series, the anvil cars essentially remained stationary. When the tank car is empty, the coupler is approximately 38 $\mathrm{mm}$ (1.5 in) higher than the coupler on the impacted hopper car.
The series of full tank car impacts consisted of nominal impact velocities of $3,6,10$, and $11 \mathrm{~km} / \mathrm{h}(2,4,6$, and $7 \mathrm{mph})$. For each impact at $3 \mathrm{~km} / \mathrm{h}$, there was approximately $300 \mathrm{~mm}$ (12 in) of movement in the anvil string. For each impact at 11 $\mathrm{km} / \mathrm{h}$, there was approximately $1000 \mathrm{~mm}$ (40 in) of movement in the anvil string. When the tank car is full, its coupler is approximately at the same height as the coupler on the impacted hopper car.

\section{Equipment}

A tank car manufactured by American Car and Foundry was used for the tests. Some critical dimensions of this car are shown in Figure 2. The tank design is denoted ACF 4-B-7188, and the under frame design is denoted ACF Industries 4-B7190 Stub Sill. The tank consists of a steel shell $11 \mathrm{~mm} \mathrm{(7/16}$ in) thick with a $102 \mathrm{~mm}$ (4 in) layer of fiberglass insulation covering the exterior of the shell. A $3.2 \mathrm{~mm}(1 / 8$ in) thick steel jacket covers the insulation. The outside diameter of the shell ranges from $2.622 \mathrm{~m} \mathrm{(103} \mathrm{1/4} \mathrm{in)} \mathrm{at} \mathrm{the} \mathrm{head} \mathrm{to} 2.746 \mathrm{~m} \mathrm{(108}$ $1 / 8$ in) at the middle. The car was designed to carry 85,463 liters $(22,577$ gallons) of detergent alkylate. The empty car weighs $335 \mathrm{kN}$ (75.4 kips). With a full payload, the car weighs $1170 \mathrm{kN}$ (263 kips). For these tests, the tank car was filled with the appropriate weight of water, resulting in a slightly greater outage than a car loaded with the same weight of detergent alkylate would. The coupler is a $61 / 4 \times 8$ type E.

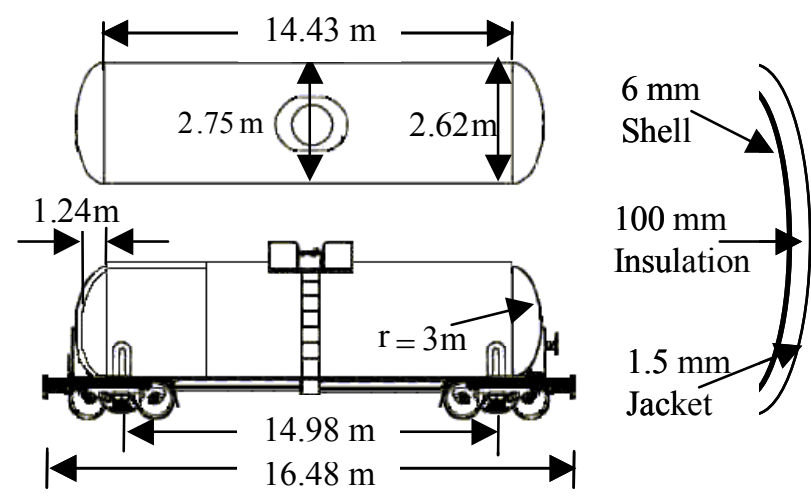

\section{Figure 2. Dimensions of tank car used in full scale impact tests.}

A Cardwell Westinghouse Mark 50 all-steel design draft gear was used on the tank car and the anvil cars. This gear design employs friction wedges and springs. There are three distinct mechanisms by which the draft gear transfers forces to the tank car [4], which are denoted by spring, stick-slip, and solid [2]. The dominant mechanism for each impact is defined as the mechanism that transfers the peak coupler force.

The spring type mechanism occurs when coupler force is transmitted through static friction in the friction wedges. The 
force versus time relationship for this type of impact is a single peak, much like that would result from a simple, albeit, stiff spring. Under quasi-static loading conditions, as much as 3600 to $4400 \mathrm{kN}$ (800 to $1000 \mathrm{kips}$ ) can be developed without breaking the friction bond. However, substantially less force can break the friction bond under dynamic loading conditions.

The stick-slip type mechanism occurs after the static friction bond is broken. Interaction between the internal spring-pack and subsequent stick-slip action of the friction wedges results in an erratic force versus time relationship. The draft gear allows $83 \mathrm{~mm}$ (3.25 inches) of travel under the stickslip mechanism.

Following the allowable travel in the draft gear, a solid load transfer mechanism is developed, where the force is transferred directly to the stub sill. Impacts where the solid load transfer mechanism is dominant are characterized by a period of erratic force versus time behavior (where the stickslip mechanism is operative) followed by a single peak with a large force. As impact speeds increase, the friction bond is broken at lower loads, and the transition through the stick-slip mechanism tends to become smoother.

\section{Instrumentation}

The tank car used in these tests was instrumented with 37 accelerometers mounted at 20 locations. These locations are shown in Figure 3. At each accelerometer location, except 11, 12 , and 17 , one accelerometer was oriented in the longitudinal direction (parallel to the track), and one accelerometer was oriented in the vertical direction (perpendicular to the ground). Locations 11, 12, and 17 each had a single accelerometer oriented in the longitudinal direction. The accelerometers mounted near the center and A-end (impacted end) of the car had a capacity of $+/-100 \mathrm{~g}$ 's and those mounted near the B-end of the car had a capacity of $+/-50 \mathrm{~g}$ 's. The acceleration data were sampled at $5000 \mathrm{samples} / \mathrm{second}$. These signals were low pass filtered at about 1000 cycles/second. An instrumented coupler was installed at the A-end of the car and used to measure longitudinal coupler force as a function of time during each test. Strains were also recorded for numerous locations on the tank car. However, strains are not discussed in this paper.

\section{EXPERIMENTAL OBSERVATIONS}

In this section, draft gear behavior, longitudinal coupler forces, and accelerations measured during the two series of tests are described.

\section{Longitudinal Coupler Forces}

Inspection of each longitudinal coupler force-time trace allows the dominant draft gear load transfer mechanism and the peak force developed during the impact to be determined. Changes in the dominant load transfer mechanism result in distinct changes in the relationship between SRS values of measured accelerations and peak coupler force [3].
A - End
B - End

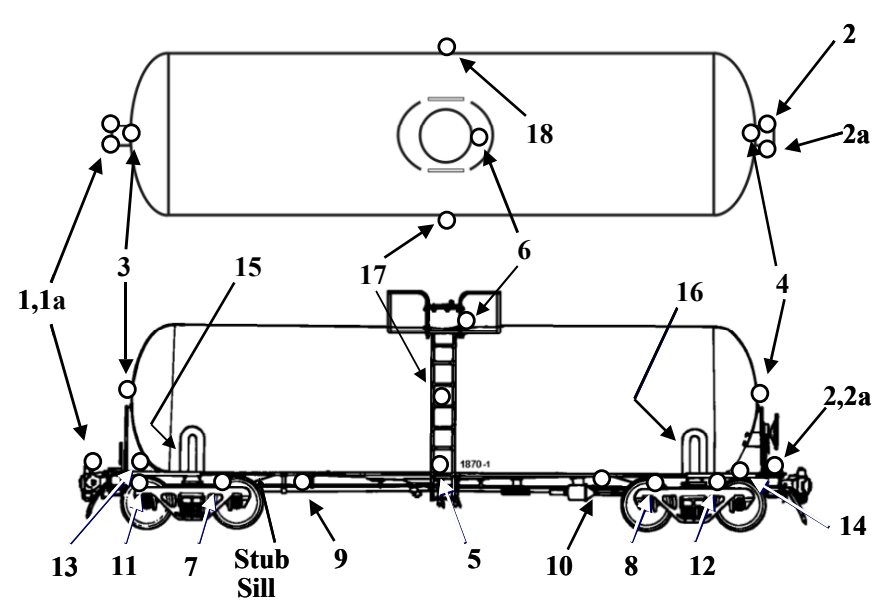

Figure 3. Locations of the accelerometers mounted on the tank car.

Longitudinal coupler forces are plotted against time in Figure 4 for sample tests representing (a) spring, (b) stick-slip, and (c) solid draft gear load transfer mechanisms for an empty tank car, and in Figure 5 for sample tests with the same draft gear load transfer mechanisms shown in Figure 4, but for a full tank car. The stick-slip behavior tends to be less pronounced in the full tank car impact tests than in the empty tank car tests. In fact, the last "bump" in Figure 5(b) might be solid load transfer. However, displacements obtained by double integrating similar-looking force histories (divided by mass to equal acceleration) suggest this hump is actually a final "stick," not a solid load transfer. A large peak in the force versus time traces following erratic changes, as shown in Figures 4(c) and 5(c), is typical of the solid load transfer mechanism. The transfer of the coupler force through solid contact in the draft gear directly into the stub sill results in the single large peak in coupler force. The force versus time traces for full tank car impact tests exhibit low frequency oscillations after the peak impact force. These oscillations are not present in the force versus time traces for empty tank car impacts, and are most likely caused by the sloshing of the lading after the initial impact.

The peak longitudinal coupler forces resulting from both series of tests are plotted against impact velocity in Figure 6 . Open symbols indicate empty car impacts and solid symbols indicate full tank car impacts. Triangle, circle, and square symbols represent spring, stick-slip, and solid draft gear load transfer mechanisms, respectively. Both series of tests resulted in qualitatively similar, but quantitatively different trends in the relationship between peak coupler force, impact speed and dominant draft gear load transfer mechanism. 


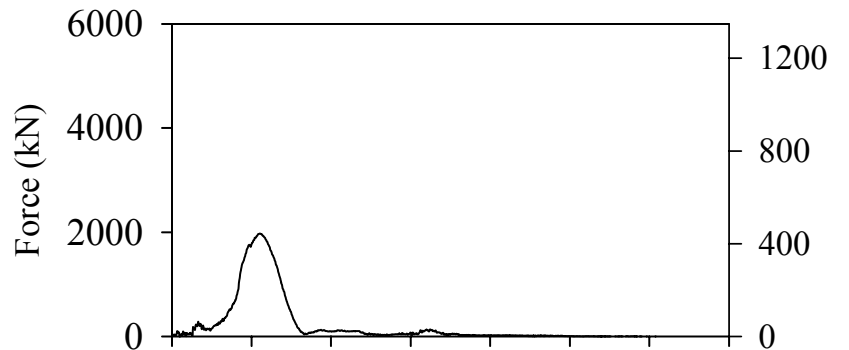

a)
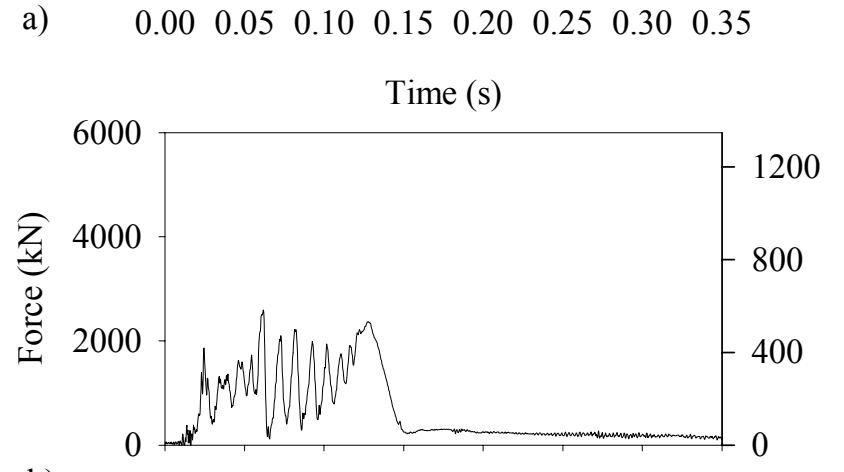

b)

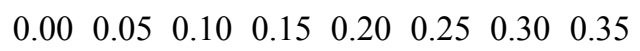

Time (s)

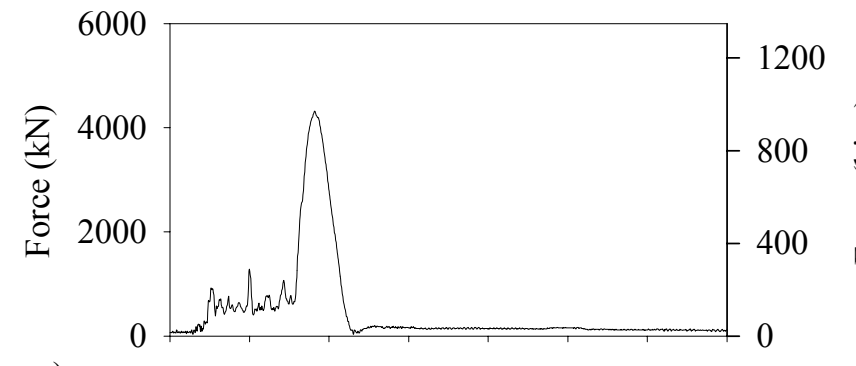

c)

$\begin{array}{llllllll}0.00 & 0.05 & 0.10 & 0.15 & 0.20 & 0.25 & 0.30 & 0.35\end{array}$

Time (s)

Figure 4. Longitudinal coupler force plotted against time for empty tank car impacts, representing (a) spring, (b) stick-slip, and (c) solid load transfer mechanisms.

For both empty tank car and full tank car impact tests, there is a general trend that the dominant draft gear load transfer mechanism is spring for the lowest impact speeds, stick-slip for the middle impact speeds, and solid for the highest impact speeds. This relation was maintained for all of the full tank car impacts, and all but one of the empty tank car impacts. The transition from the spring mechanism to the stick-slip mechanism occurs at a lower impact speed for the full tank car impacts (approximately $5 \mathrm{~km} / \mathrm{h}(3 \mathrm{mph}))$ than for the empty tank car impacts (between 6 and $8 \mathrm{~km} / \mathrm{h}(4$ and $5 \mathrm{mph})$ ). The transition from the stick-slip mechanism to the solid mechanism occurs at approximately $10 \mathrm{~km} / \mathrm{h}(6 \mathrm{mph})$ for the empty tank car impacts and between 7 and $10 \mathrm{~km} / \mathrm{h}$ for the full tank car impacts.

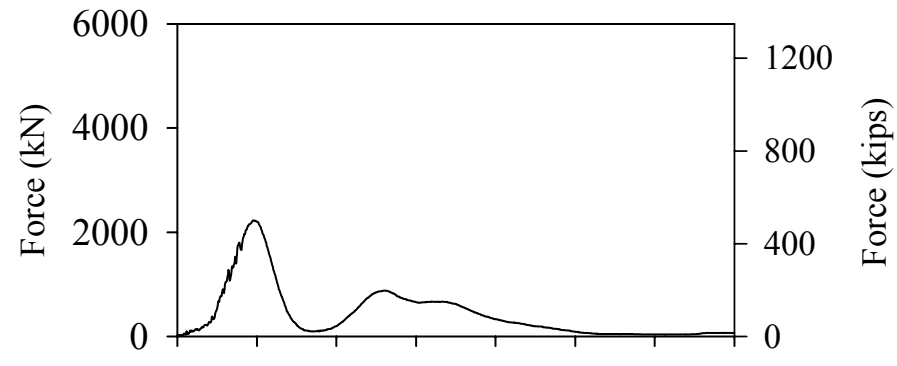

a) $\quad \begin{array}{llllllll}0.00 & 0.05 & 0.10 & 0.15 & 0.20 & 0.25 & 0.30 & 0.35\end{array}$

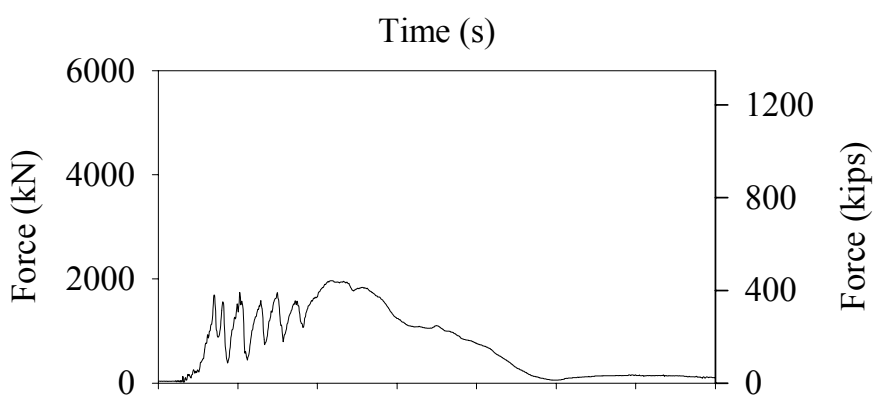

b) $\quad \begin{array}{llllllll}0.00 & 0.05 & 0.10 & 0.15 & 0.20 & 0.25 & 0.30 & 0.35\end{array}$

Time (s)

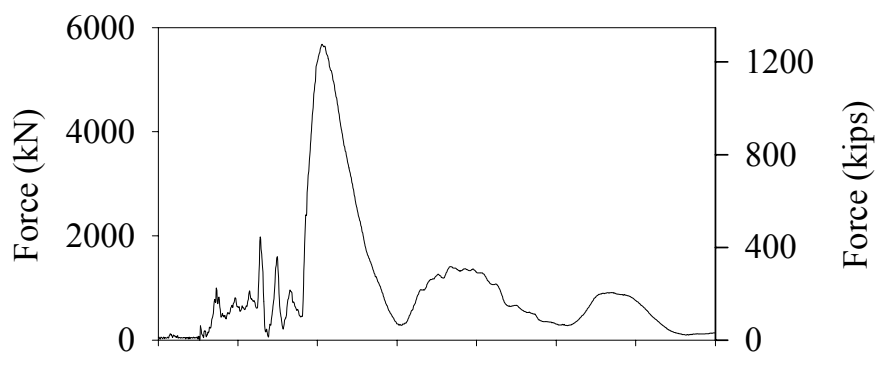

c)

$\begin{array}{llllllll}0.00 & 0.05 & 0.10 & 0.15 & 0.20 & 0.25 & 0.30 & 0.35\end{array}$

Time (s)

Figure 5. Longitudinal coupler force plotted against time for full tank car impacts, representing (a) spring, (b) stick-slip, and (c) solid load transfer mechanisms.

The five spring mechanism impacts for the empty tank car have a general trend of increasing peak longitudinal coupler force with increasing impact speed. However, there is some scatter in this relationship. All five spring mechanism impacts for the full tank car have approximately the same impact speed and the same peak longitudinal coupler force. For spring mechanism impacts at a given speed, the full tank car develops higher peak longitudinal coupler forces than the empty tank car develops.

The three stick-slip mechanism impacts for the empty tank car all have peak longitudinal coupler force values of approximately $2600 \mathrm{kN}$ (585 kips), and a range of impact speeds from 6 to $10 \mathrm{~km} / \mathrm{h}$ (4 to $6 \mathrm{mph}$ ). The five stick-slip 
mechanisms impacts for the full tank car all have peak longitudinal coupler force values of approximately $2000 \mathrm{kN}$ (450 kips) and a range of impact speeds from 5 to $7 \mathrm{~km} / \mathrm{h}$ ( 3 to $5 \mathrm{mph})$.

The four solid mechanism impacts for the empty tank car exhibit increasing peak longitudinal coupler force with increasing impact speed. The five solid mechanism impacts for the full tank car also exhibit increasing peak longitudinal coupler force with increasing impact speed. For solid mechanism impacts at a given speed, the full tank car develops higher peak longitudinal coupler forces than the empty tank car develops.

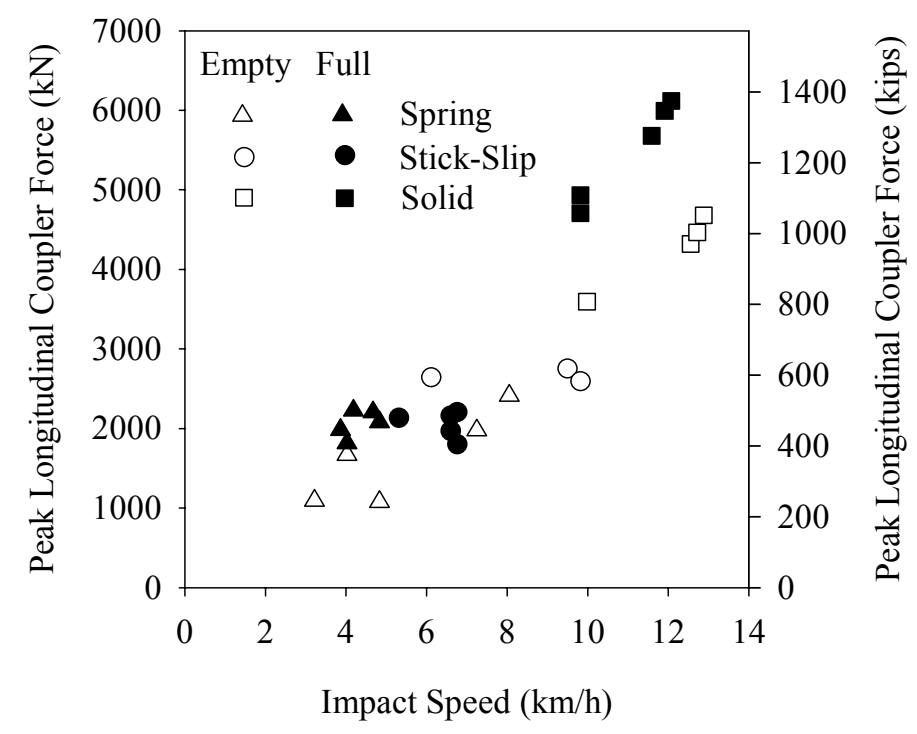

Figure 6. Peak longitudinal coupler forces plotted against impact velocity for an empty and full tank car.

\section{Measured Accelerations}

For each impact, the responses of all accelerometers were recorded over time. As examples, accelerations measured at location 6 (at the top of the car near the manway) are plotted for impacts with solid load transfer mechanisms for an empty and a full tank car test. Longitudinal and vertical accelerations measured at location 6 are plotted against time for an empty tank car impact in Figures 7(a) and Figure 7(b), respectively. Longitudinal and vertical accelerations measured at location 6 are plotted against time for a full tank car impact in Figures $8(\mathrm{a})$ and Figure $8(\mathrm{~b})$, respectively. The resulting peak longitudinal coupler forces for these impacts are $4200 \mathrm{kN}$ (1052 kips) for the test represented in Figure 7 and $5500 \mathrm{kN}$ (1370 kips) for the test represented in Figure 8.
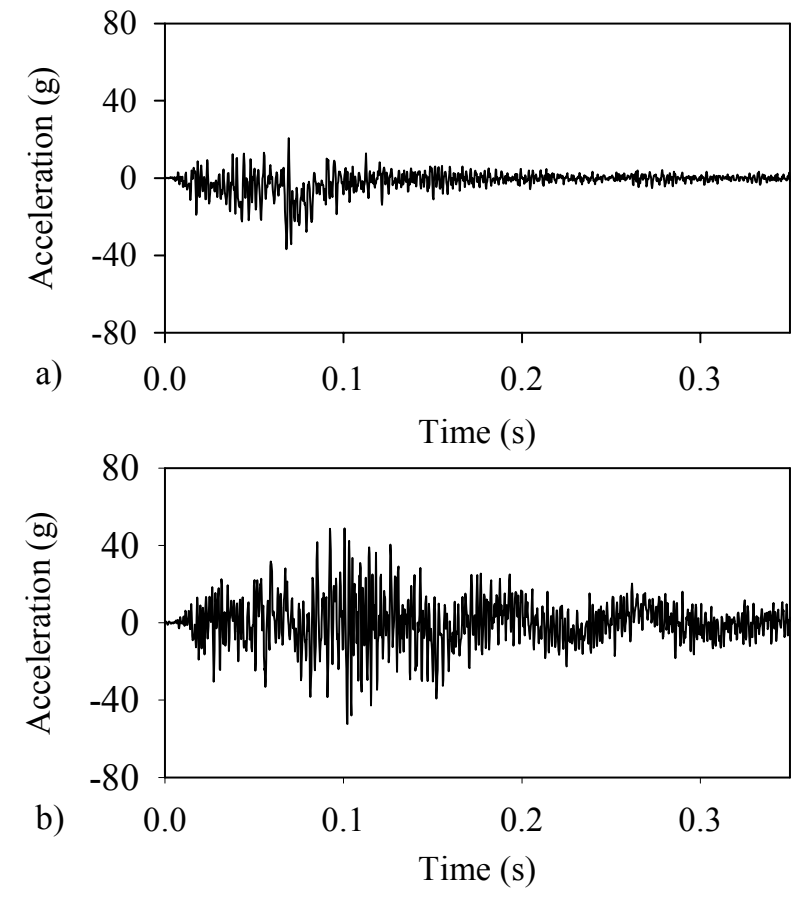

Figure 7. Accelerations from an empty tank car impact measured at location 6 in the (a) longitudinal direction and (b) vertical direction.
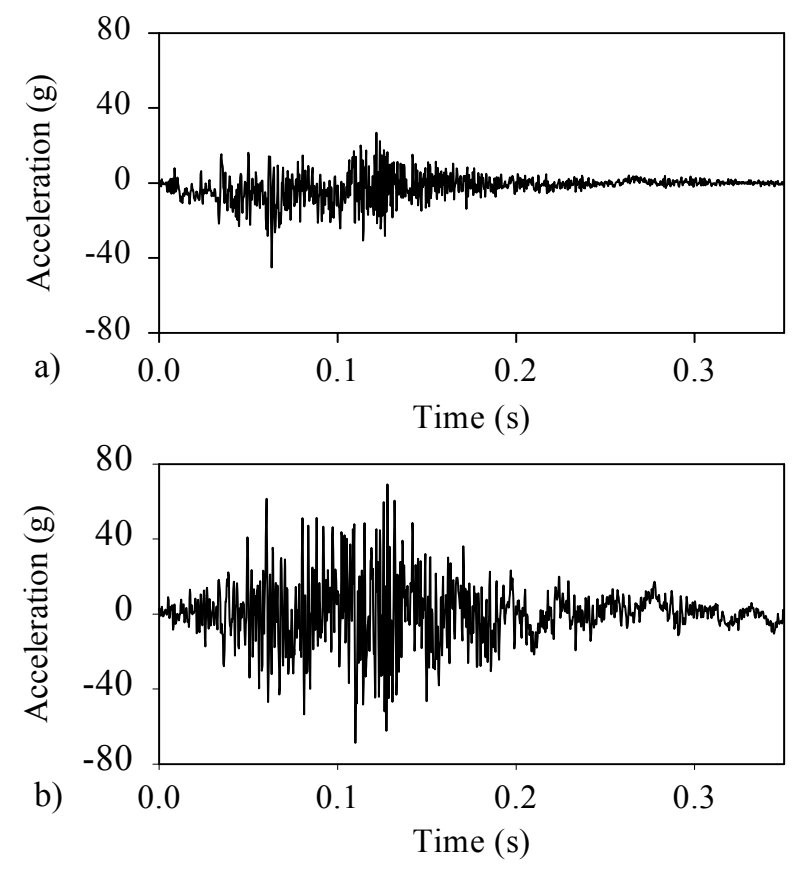

Figure 8. Accelerations from a full tank car impact measured at location 6 in the (a) longitudinal direction and (b) vertical direction. 


\section{ANALYSIS AND DISCUSSION}

The results from the Shock Response Spectrum (SRS) and the power spectral density (PSD) analyses performed on the measured accelerations are presented, and the effect of tank car lading, peak coupler force, the dominant draft gear mechanism on the response of the accelerometers are discussed in this section.

\section{Shock Response Spectrum}

The Shock Response Spectrum (SRS) is often used to quantify a shock loading. The SRS is the peak acceleration response of hypothetical systems with a range of natural frequencies, and in this case, 5\% damping. To establish a single value to quantify each acceleration trace, linear averages of SRS values for frequencies of 5 to $50 \mathrm{~Hz}$ at $5 \mathrm{~Hz}$ intervals are used. The resulting average SRS values are plotted against peak longitudinal coupler force in Figure 9. Open markers indicate SRS results for the empty tank car tests. Filled markers indicate SRS results for the full tank car tests. Each test series results in a relationship between average SRS and peak longitudinal coupler force. However, the empty tank car and full tank car tests result in different relationships.

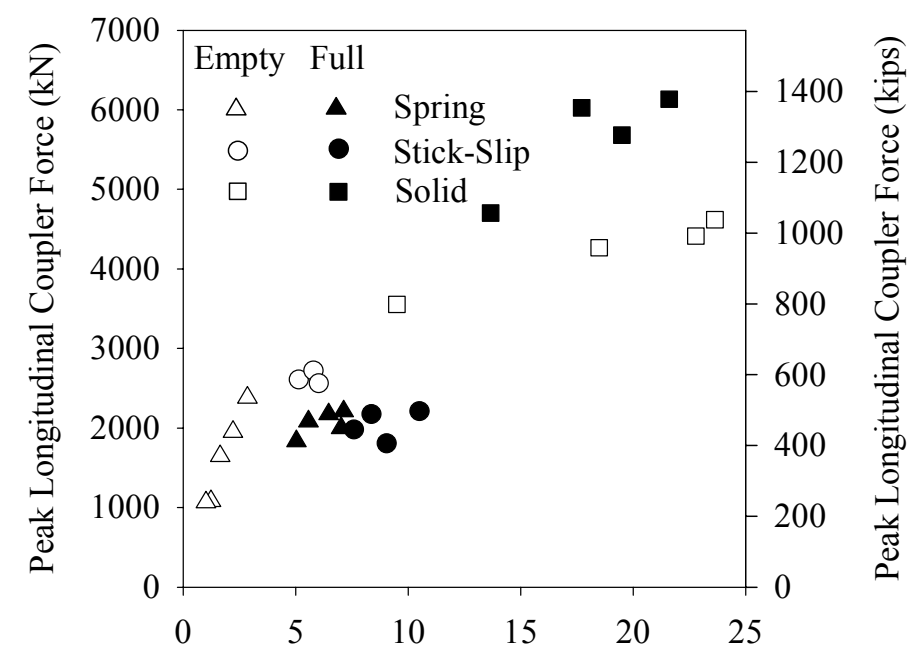

Average SRS (g)

\section{Figure 9. Average SRS of longitudinal acceleration at location 6 plotted against peak longitudinal coupler forces.}

For the empty tank car test, there are three distinct regions on each curve, which correspond to three different draft gear load transfer mechanisms. At low average SRS values (less than $4 \mathrm{~g}$ ) there is a linear relationship between the average SRS and the peak longitudinal coupler force. Near an average SRS value of $5 \mathrm{~g}$ there are three stick-slip impacts with nearly the same average SRS value and the same peak longitudinal coupler force. At higher average SRS values there are four solid impacts where the peak longitudinal coupler forces increase with increasing average SRS values.

For the full tank car tests, there are five spring impacts with average SRS values less than $7.5 \mathrm{~g}$. There are four stickslip impacts with SRS values greater than $7.5 \mathrm{~g}$. For these tests, average SRS value predicts the transition from spring to stick-slip. However, the peak longitudinal coupler force for all nine of these impacts is approximately $2000 \mathrm{kN}$ (450 kips). Four solid impacts have average SRS values of approximately $14 \mathrm{~g}$ or higher, with the general trend that peak longitudinal coupler force tends to increase with increasing average SRS value.

\section{PSD Analysis of Accelerations}

A power spectral density analysis (PSD) [3] was performed on each tank car test acceleration history to determine the dominant frequencies in the response of the tank car. Accelerations in both the vertical and longitudinal directions for the empty and full tank car tests were examined. Before these results could be considered, a consistent manner to analyze these data, as well as a relatively limited number of acceleration traces to study had to be identified.

The results of PSD analyses on these acceleration traces are dependent on the portion of the signal that is analyzed. To determine the optimal portion of the signal to analyze for the PSD calculations, a consistent method to identify a start time and a constant window size was established. Doubledifferentiating the acceleration signal and setting a reasonable threshold value, determined to be $2 \times 10^{7} \mathrm{~g} / \mathrm{sec}^{2}$, was used to identify the start time. No sensitivity studies were performed on the start time, but this value resulted in the same start time as when using engineering judgment, except in a $2 \mathrm{mph}$ impact for an empty tank car, where a threshold value of $1 \times 10^{7} \mathrm{~g} / \mathrm{sec}^{2}$ identified the correct start time. To investigate the most appropriate value for the window, a series of analyses were performed on selected acceleration histories. For these analyses, the window of signal was varied between 0.2 and 1.0 seconds in increments of 0.05 seconds. Varying the window size changed the results of the PSD analyses. To visualize these results, a plot of PSD analyses, frequency, and the window size was developed for the acceleration histories. A sample three-dimensional plot for a stick-slip impact is shown in Figure 10. For a given window size, certain frequencies exhibit peaks in the PSD. When these peaks are consistent for a range of window values, the peaks appear as "fans" in the three-dimensional plot that run parallel to the window axis and perpendicular to the frequency axis. It was assumed that the peaks that are consistent throughout the range of windows are the most significant. Based on these results, a window of 0.35 seconds was chosen and used for all additional analyses. 


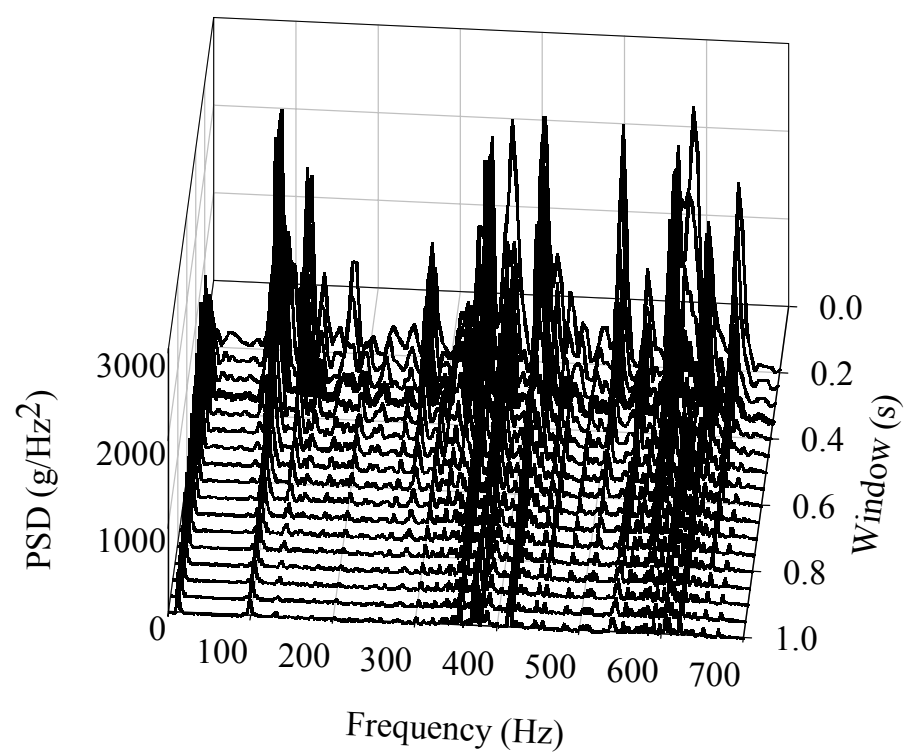

Figure 10. PSD results for vertical accelerations from an empty tank car impact with a stick-slip coupler mechanism as a function of window of signal examined The PSD plot obtained for a window of 0.35 seconds, selected as the representative response, is shown in bold.

The results of PSD analyses for a given impact are dependent on the location at which the acceleration is measured. PSD results for vertical accelerations from a stickslip type impact, measured at location 1 (at the A-end of the car), location 6 (near the manway in the middle of the car), and location 16 (at the B-end of the car) are shown in Figure 11. These results are typical of those observed near the two ends and the middle of the tank car. Locations at the A-End (impacted end) of the tank car (1, 1A, 3, 7, 11, 13, and 15) have peaks at numerous frequencies that make it difficult to identify any specific frequencies of note. Locations at the B-end of the tank car $(2,2 \mathrm{~A}, 4,8,10,14$, and 16) tend to have relatively weak responses that also make it difficult to identify specific frequencies. Accelerations measured in the middle of the car, such as locations 5 and 6 , were felt to be a good compromise between the two ends, and therefore the best locations to observe structural response. The response at location 5 appears to be affected by interaction from stiffener beams and lading (for full car impacts). As a result, location 6 was chosen for careful consideration.

\section{PSD Results Near the Manway}

Power spectral density analyses were performed on 0.35 second windows of acceleration histories measured at all locations, but analyses of location 6 are discussed herein. A plot of the PSDs for the longitudinal signals from location 6 for one empty tank car impact for each type: spring, stick-slip, and solid are shown in Figure 12. A plot of the PSDs for the vertical acceleration signals from location 6 for one empty tank car impact for each type: spring, stick-slip, and solid, are shown in Figure 13. A plot of the PSDs for the longitudinal signals from location 6 for one full tank car impact for each type: spring, stick-slip, and solid are shown in Figure 14. A plot of the PSDs for the vertical acceleration signals from location 6 for one full tank car impact for each type: spring, stick-slip, and solid are shown in Figure 15.
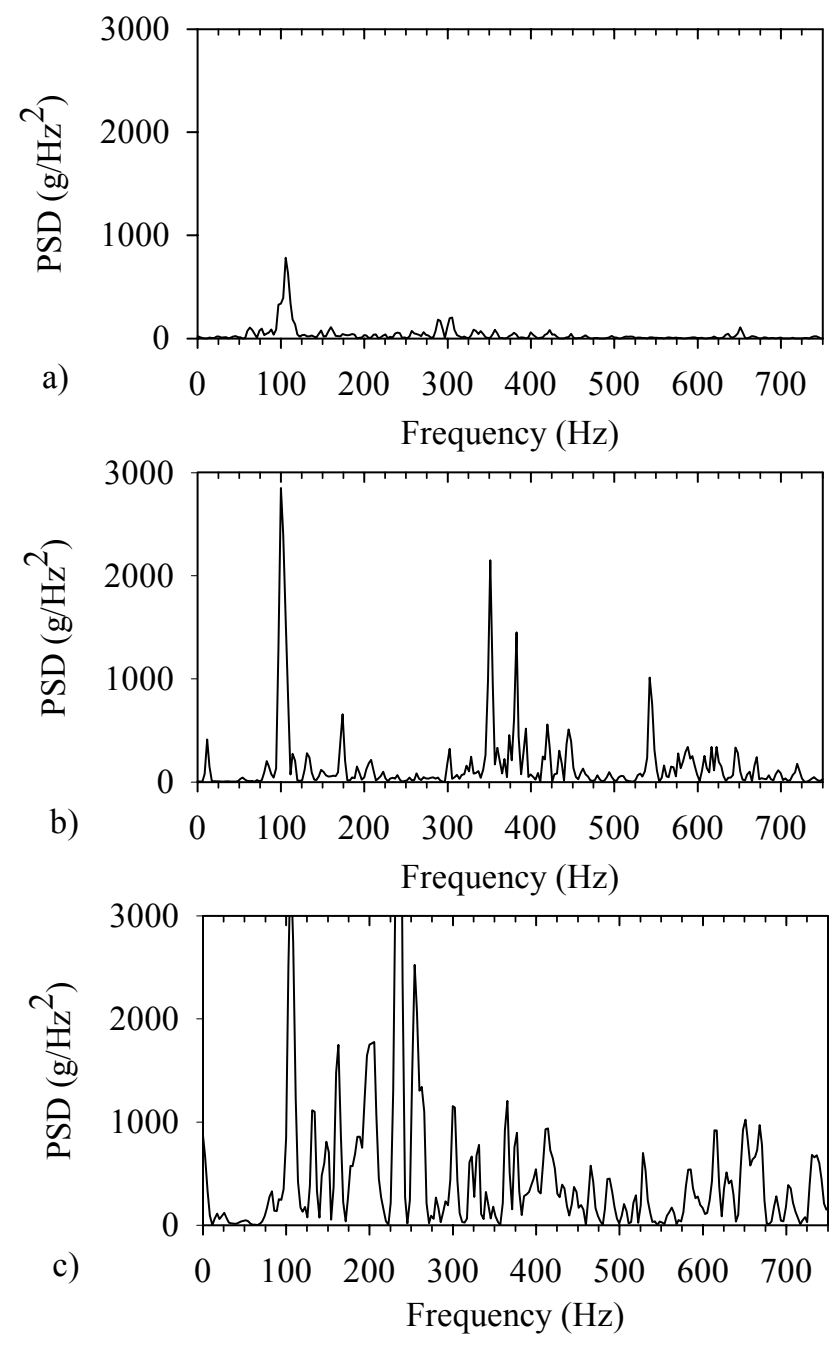

Figure 11. PSD analyses of vertical accelerations measured at a) location 2 (B-end), b) location 6 (manway), and c) location 1 (A-end). 
The PSD analyses plotted in Figure 10 show a group of peaks at frequencies near $400 \mathrm{~Hz}$ and another group of peaks at frequencies near $600 \mathrm{~Hz}$. Although most tests had similar groups of peaks near 400 and $600 \mathrm{~Hz}$, no specific frequencies or trends were observed to be repeated from test to test. Furthermore, theses frequencies are relatively high compared to most low mode number structural frequencies [5]. Therefore, these high-frequency peaks are not discussed further.

Repeatable trends were observed for peaks that occur at lower frequencies. The PSD results from the empty tank car impacts, shown in Figures 12 and 13, exhibit dominant peaks at $0 \mathrm{~Hz}$ in the longitudinal direction and $13 \mathrm{~Hz}$ in the vertical direction. The PSD results from the full tank car test, shown in Figures 14 and 15, exhibit dominant peaks at $0 \mathrm{~Hz}$ in the longitudinal direction and at both $5 \mathrm{~Hz}$ and $23 \mathrm{~Hz}$ in the vertical direction. The frequency of $0 \mathrm{~Hz}$ is not a vibration. Rather, it represents translation or acceleration in a single direction. In addition, a peak at $100 \mathrm{~Hz}$ occurs for vertical accelerations for empty tank car impacts with a stick-slip coupler mechanism. This peak also occurs for many full tank car impacts. However, the $100 \mathrm{~Hz}$ peaks are not as significant for the full tank car impacts as the empty tank car impacts. The $100 \mathrm{~Hz}$ frequency corresponds to oscillations in the coupler force vs. time traces observed for impacts with a stick-slip draft gear mechanism. The difference between the empty and full tank car results can be attributed to the natural frequencies of each car. The natural frequency is a function of stiffness or mass. The full tank car contains lading, which increases the mass compared to the empty tank car, and changes the natural frequency.

\section{SUMMARY AND CONCLUSIONS}

The purpose of this paper is to investigate the response of a tank car to coupler impacts, with the ultimate goal of developing an accelerometer-based system to monitor high coupler force events. Shock Response Spectrum analyses (SRS) and Power Spectral Density analyses (PSD) were performed on measured accelerations to quantify the response of the tank car to the impacts. The effects of tank car loading, peak coupler force, and dominant draft gear mechanism on the accelerometer responses were considered. This systematic study of tank car behavior will help to establish, understand, and gain confidence in empirical relationships between SRS and peak longitudinal coupler force that will be developed from these tests.

Coupler force is transmitted through the draft gear to the tank car stub sill by three draft gear mechanisms: spring, stickslip, and solid. For any given impact, longitudinal coupler forces can be transferred by one or more of these mechanisms. The dominant draft gear mechanism is defined as the mechanism under which the peak longitudinal coupler force is developed. Operative draft gear mechanisms can be discerned by observing longitudinal coupler force versus time relationships.
An ideal location to measure accelerations was identified. PSD analyses of accelerations measured at the striking end experienced a significant amount of noise while locations at the other end did not develop a strong signal. Locations at the middle and bottom of the tank car were affected by lading and structural supports along the bottom of the tank car. A location near the manway was found to be the best location for study.

There is a good correlation between the SRS of longitudinal accelerations measured at location 6 and peak coupler force. The relationship between SRS and peak coupler force is different when the tank car is empty than when the tank car is full. Therefore, if SRS is to be used to determine peak coupler forces resulting from impacts, it is important that the load state of a tank car is known.
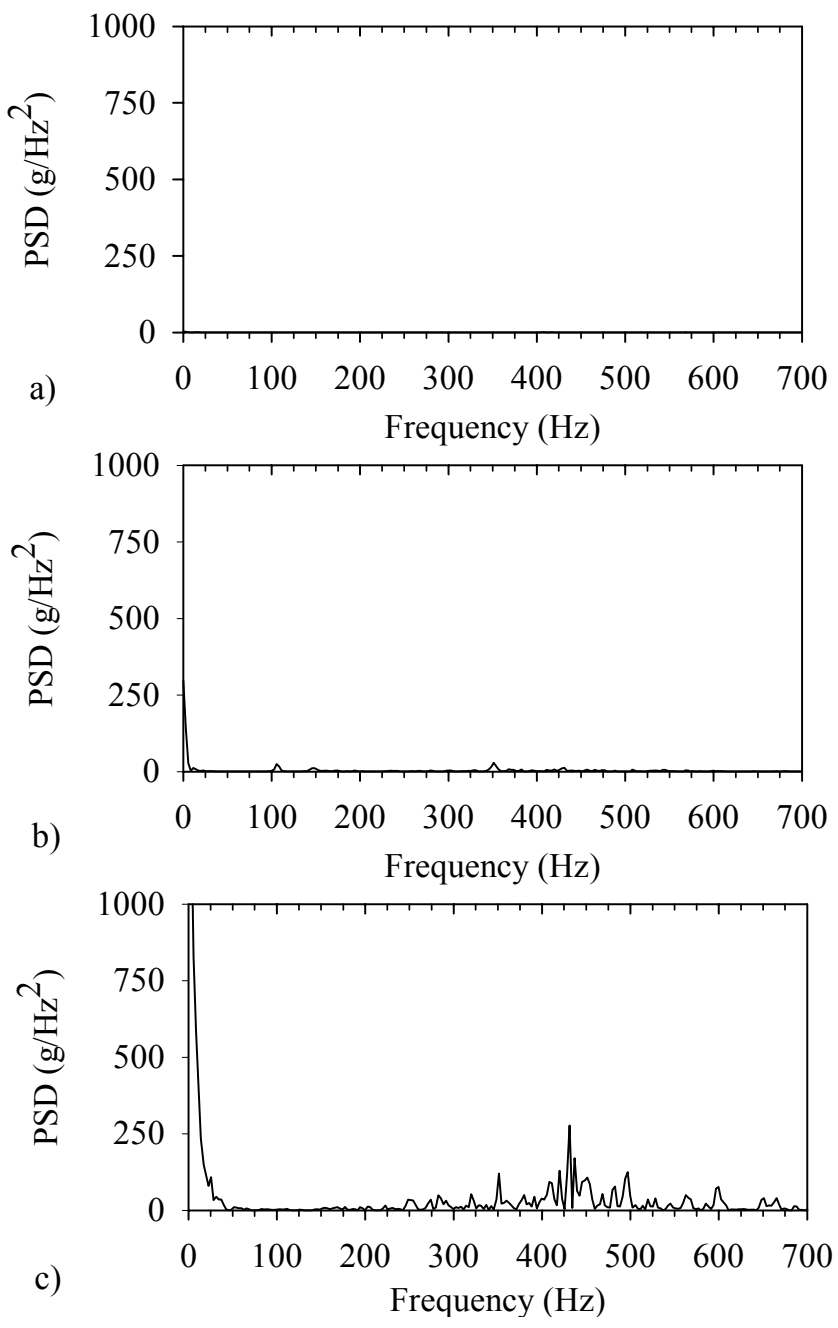

Figure 12. PSD of longitudinal accelerations from location 6 for (a) spring, (b) stick-slip, and (c) solid load transfer mechanisms for an empty tank car. 
The dominant draft gear load transfer mechanism affects the SRS and PSD results. For impacts were the stick-slip mechanism is dominant, a $100 \mathrm{~Hz}$ peak is apparent in the PSD results of the vertical accelerations from both empty and full tank car impacts. This frequency correlates to the frequency of oscillation in coupler force versus time relationship during an impact with a stick-slip draft gear mechanism. Distinct kinks in the average SRS versus peak longitudinal coupler force relationship correspond to changes in the coupler force mechanism.

The PSD analyses of acceleration histories recorded at location 6 indicate significant differences between the behavior
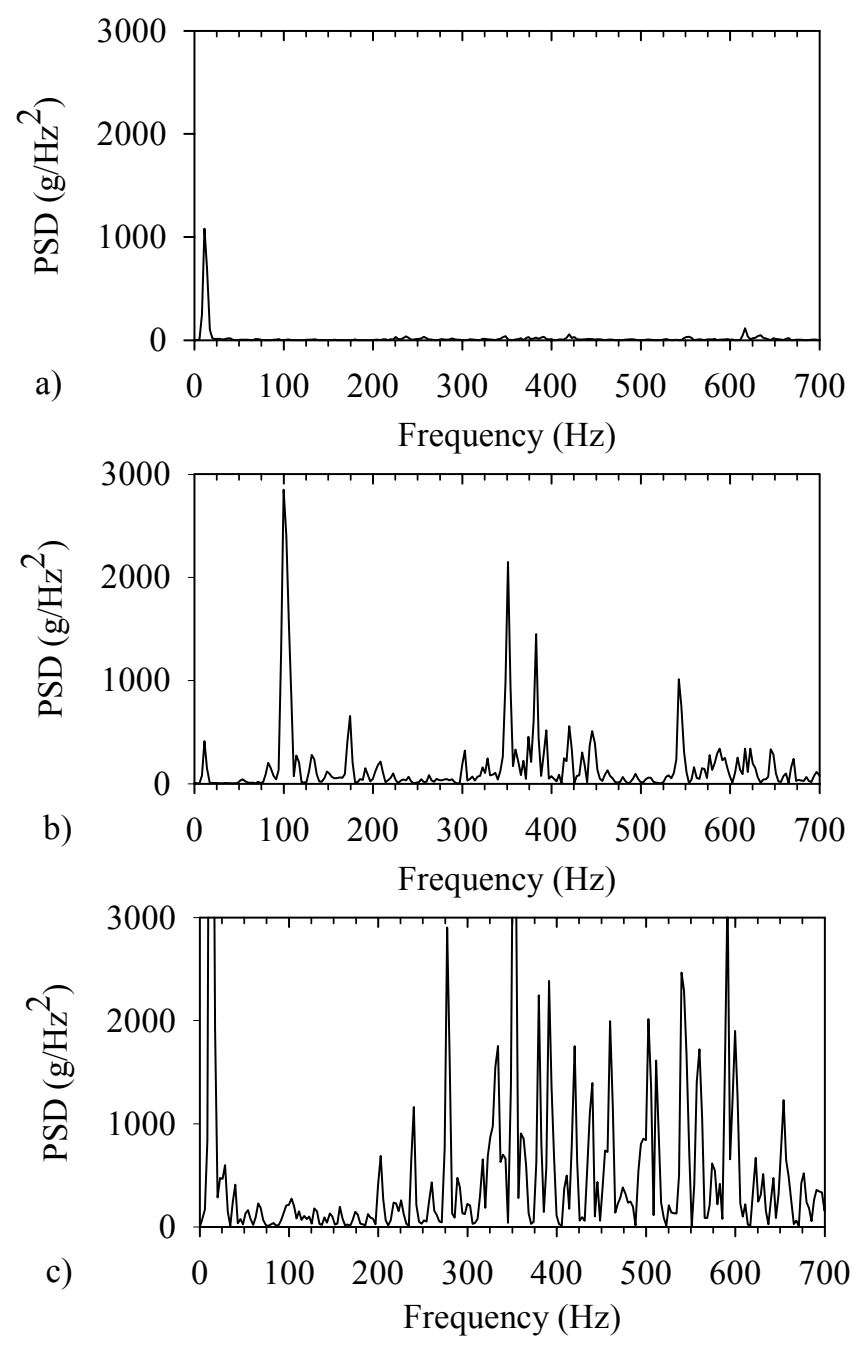

Figure 13. PSD of vertical acceleration from location 6 for (a) spring, (b) stick-slip, and (c) solid load transfer mechanisms for an empty tank car. of the empty tank car and the behavior of the full tank car. The PSD analyses show dominant and repeatable peaks at $0 \mathrm{~Hz}$ for the longitudinal accelerations and $13 \mathrm{~Hz}$ for the vertical accelerations in the empty tank car tests, and dominant and repeatable peaks at $0 \mathrm{~Hz}$ for the longitudinal accelerations and at both $5 \mathrm{~Hz}$ and $23 \mathrm{~Hz}$ for the vertical accelerations in the full tank car test.

The systematic study of the relationships between structural response, peak coupler force, draft gear behavior, impact speed and tank car load state will help identify and gain confidence in empirical relationships between SRS and peak coupler force that are developed as a result of these tests.
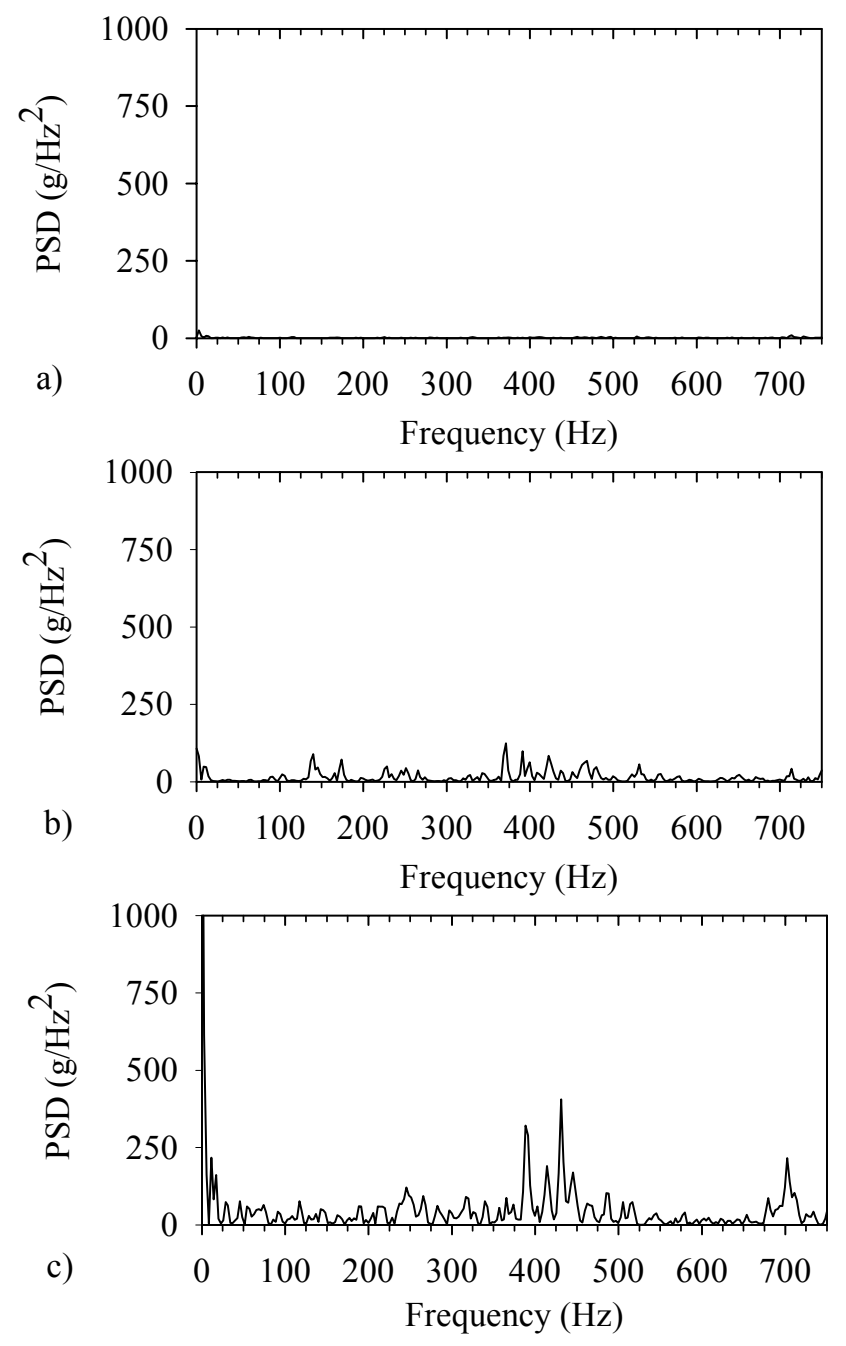

Figure 14. PSD of longitudinal accelerations from location 6 for (a) spring, (b) stick-slip, and (c) solid load transfer mechanisms for a full tank car. 

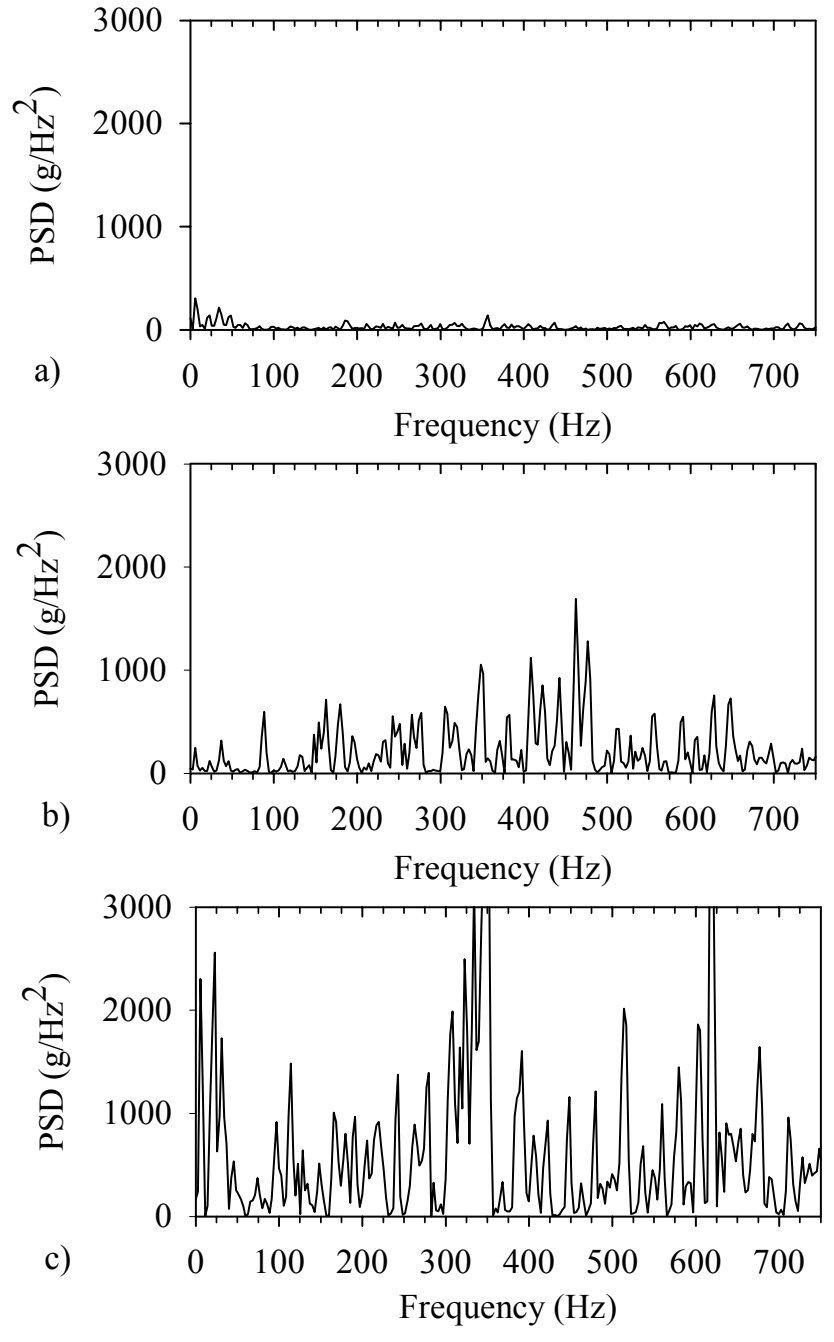

Figure 15. PSD of vertical acceleration from location 6 for (a) spring, (b) stick-slip, and (c) solid load transfer mechanisms for a full tank car.

\section{ACKNOWLEDGMENTS}

The work that is described in this paper resulted from a cooperative effort between industry groups and federal agencies. As a result, we are indebted to many people and organizations. The Tank Car Operating Environment Task Force was established by the AAR-CMA-RPI liaison team to oversee this project. The Stub Sill Working Group was also responsible for overseeing the project. This project was funded by RPI (now RSI), AAR, Transport Canada, and the FRA Office of Research and Development. The PSD analyses, and compilation of this paper were funded by the FRA. The FRA Office Research and Development tank car safety program manager is Mr. Jose Pena. The tank car was donated by Union Tank Car Company. Mr. Al Henzi and Mr. Phil Daum facilitated this donation. Mr. Keith Smith, of Southwest
Research Institute (SWRI), formerly of TTCI, was responsible for much of the original design of the project. Todd Treichel, of RPI-AAR, and Christopher Barkan, University of Illinois are thanked for contributions to this project.

\section{REFERENCES}

1. Smith, K. B., Parker, E. S., Iler, D. J., "Rail Car Service Spectra Generation for Full-Scale Accelerated Fatigue Testing," in Applications of Automated Technology in Fatigue and Fracture Testing and Analysis, ASTM STP 1411, A. A. Braun, P. C. McKeighan, M. A. Nicholson and P. R. Lohr, Eds., American Society for Testing and Materials, West Conshohocken, PA, pp. 62-84, 2002.

2. Koch, K. D., Riddell, W. T., Treichel, T. T., Barkan, C. P. L., "Structural Response and Coupler Forces During Tank Car Impacts," 43rd Mechanical Working and Steel Processing Conference Proceedings, Vol. XXXIX, Iron and Steel Society, Warrendale, PA, pp. 837-848, 2001.

3. Thompson, William T., "Transient Vibration," Theory of Vibrations with Applications, Third Edition, Prentice Hall, New Jersey, 1988.

4. Sommerfield, H., (Engineer at Cardwell/Westinghouse Air Brake Company) personal communication (with K.D. Koch), January 2001.

5. Blevins, Robert D., Formulas for Natural Frequency and Mode Shape, Krieger Publishing Company, Florida, pp. 300-305, 1979.

6. Lyons, M. L., Riddell, W. T., Koch, K. D., "Analysis of Accelerations Measured During Full-Scale Tank Car Impact Tests," DOT/FRA/RDV-XX/XX. 